\title{
Accuracy of Precision Diagnostic Blocks in the Diagnosis of Chronic Spinal Pain of Facet or Zygapophysial Joint Origin: A SYSTEMATIC REVIEW
}

\author{
Mark V. Boswell, MD, PhD, Vijay Singh, MD, Peter S. Staats, MD, and Joshua A. Hirsch, MD
}

Context: Facet or zygapophysial joint blocks are used extensively in the evaluation of chronic spinal pain. However, there is a continuing debate about the value and validity of facet joint blocks in the diagnosis of chronic spinal pain. The value of diagnostic facet joint injections may have been overlooked in the medical literature.

Objectives: To determine the accuracy of facet joint blocks in the diagnosis of chronic spinal pain of facet joint origin and also determine the rationale, principles, false-positive rate, and diagnostic utility of facet joint blocks as well as prevalence of facet joint pain.

Methods: Relevant literature was identified through searches of MEDLINE, EMBASE (Jan
1966- Mar 2003), manual searches of bibliographies of known primary and review articles, and abstracts from scientific meetings. Studies were selected if they were either placebo-controlled or comparative local anesthetic blocks and met 3 of the 5 criteria established by the Agency for Healthcare Research and Quality.

Information extracted from each study included the details about the study, type, design, patient eligibility criteria, and statistical analysis. Studies were excluded from analysis if they were simply a review or descriptive or involved only a single-block.

Results: The data showed that there was conclusive evidence demonstrating that facet joints have a nerve supply and are ca- pable of causing pain with provocation in normal volunteers that reproduces typical pain attribution clinically to facet joints. The studies demonstrated a prevalence of facet joint pain in chronic spinal pain patients of $15 \%$ to $45 \%$ in lumbar spine, up to $48 \%$ in thoracic spine, and $54 \%$ to $67 \%$ in the cervical spine. Single diagnostic blocks showed a false-positive rate of $27 \%$ to $63 \%$.

Conclusion: The diagnostic accuracy of controlled local anesthetic facet joint blocks is high in the diagnosis of chronic spinal pain.

Keywords: Spinal pain, facet joints, zygapophysial joints, diagnostic blocks, comparative local anesthetic blocks
Medical literature continues to report that back pain cannot be diagnosed in up to $85 \%$ of cases (1-4), despite the fact that there is an extensive literature on the value of diagnostic injection techniques for determining precise causes of low back pain (5-33). The purpose of this review article is to critically evaluate recent evidence regarding the prevalence of back pain attributed to the facet or zygapophysial joints and to evaluate the efficacy of injection techniques in the diagnosis of facet pain. This review may point to clinically useful treatment options and help dispel prevalent nihilistic thinking regarding chronic spinal pain.

Pivotal to the proper management of chronic spinal pain is the ability to pinpoint an anatomical diagnosis. For this purpose, physical examination is neither

From Case Western Reserve University School of Medicine, Cleveland, $\mathrm{OH}$, Pain Diagnostic Associates, Niagara, WI, John Hopkins University School of Medicine, and Massachusetts General Hospital, Harvard School of Medicine, Boston, MA. Address Correspondence: Mark V. Boswell, MD, 11100 Euclid Avenue, Cleveland, $\mathrm{OH}-44106$. E-mail: boswellmv@earthlink.net

Funding: There was no external funding in preparation of this manuscript. reliable nor valid (31). Medical imaging provides little sound information (34). It is often cited that a cause cannot be determined in $85 \%$ of patients with low back pain (1-4) or conversely, that a diagnosis is possible in only some $10 \%$ to $15 \%$ of cases $(4,35,36)$. No technique of physical examination has sufficient reliability and validity to allow a patho-anatomic diagnosis to be made $(4,34)$. Radiographic investigations, including magnetic resonance imaging (MRI), reveal only some conditions with certainty (34).

In the 1990's, new precision diagnostic tests have been developed, evaluated and implemented. Thus, if appropriate tests are used, a diagnosis of chronic spinal pain can be made in at least $50 \%$ of the cases, and perhaps in as many as $70 \%$ of the cases $(5,6,8-10,31,32)$. These precision diagnostic techniques include facet or zygapophysial joint blocks, provocative discography, and sacroiliac joint blockade.

Central to the understanding of the structural basis of chronic spinal pain is the provision of a physical diagnosis and validation of patient symptomatology whenever it is feasible rather than discounting emotional involvement. This concept will remove many of the terms utilized in the past such as "psychogenic," "somatizing," "hysterical," and more recently, "medically unexplained," to explain many of the pain problems not amenable to diagnosis by present methodology utilizing physical examination, radiological and electrodiagnostic testing.

Bogduk (5) postulated that, for any structure to be deemed a cause of back pain:

- The structure should have a nerve supply;

- The structure should be capable of causing pain similar to that seen clinically, ideally demonstrated in normal volunteers;

- The structure should be susceptible to diseases or injuries that are known to be painful; and,

- The structure should have been shown to be a source of pain in patients, using diagnostic techniques of known reliability and validity.

The same philosophy may be applied for thoracic and neck pain. Kuslich et al (37) identified facet joints, ligaments, fascia, muscles, intervertebral discs, and 
nerve root dura as tissues capable of transmitting pain in the low back. Facet joints have been proven to be common sources of pain with proven diagnostic techniques (4-6, 31-33).

Bogduk (6) also postulated that diagnostic blockade of a structure with a nerve supply with the ability to generate pain can be performed to test the hypothesis that the target structure is a source of the patient's pain. Advantages of the needle procedures are that discs and joints of the spine which are not accessible to palpation are accessible to needles introduced onto or into these target structures under fluoroscopic guidance. Compared to palpation, needle procedures have the advantage that they can target a particular structure selectively and accurately. Radiography can be used to confirm that the target structure, and only the target structure, has been reached by the needle or by anything that is injected through it (31). Further, precision diagnostic needle procedures can determine, physiologically, whether or not the target structure is painful. However, imaging studies do not do this. Finally, the major advantage is the critical evaluation of the precision diagnostic blocks as they can be subjected to controls to ensure the validity of the test in each and every patient. Hildebrandt (7) published an extensive review on the relevance of nerve blocks in treating and diagnosing low back pain. Saal (33) has reviewed general principles of diagnostic testing of painful lumbar spine disorders and evaluated diagnostic tests and their inherent limitations.

The popularity of precision diagnostic injections as a diagnostic tool in painful conditions is due to several features. Hogan and Abram (38) described multiple challenging clinical situations, including the characteristics of chronic pain, which are purely subjective and the conditions which are, in most cases, inexactly defined with uncertain pathophysiology. Precision diagnostic blocks are used to clarify these challenging clinical situations, in order to determine the pathophysiology of clinical pain, the site of nociception and the pathway of afferent neural signals. They also reported that clinical studies of precision diagnostic techniques are variable, not only in quality, but also in quantity.

It is of paramount importance to determine the false-positive rate (how often patients without a condition will none- theless have a positive test), and false-negative rate (how often a patient with disease will have a negative test). The general parameters of accuracy are described as the specificity and sensitivity of the diagnostic test. Specificity is a relative measure of the prevalence of false-positives, whereas sensitivity is the relative prevalence of false-negative results. The most sensitive test will be positive for all cases in which the disease is present. The specificity is greatest when there is a positive test result only when the disease is present. Thus, the ideal diagnostic test would have a sensitivity of $100 \%$ and a specificity of $100 \%$. Since none of the tests available in clinical medicine have these ideal features, there is a degree of uncertainty regarding the accuracy of each and every diagnostic test as applied to an individual clinical case.

Hildebrandt (7), in an extensive review on the relevance of diagnostic zygapophysial joint blocks, concluded that the diagnostic use of neural blockade rests on three premises. First, the pathology causing pain is located in an exact peripheral location, and impulses from this site travel via unique and consistent neural route. Second, injection of local anesthetic totally abolishes the sensory function of intended nerves and does not affect other nerves. Third, relief of pain after local anesthetic block is attributable solely to the block of the target afferent neural pathway.

Saal (33) described that the test used to diagnose the source of chronic low back pain requires accurate determination of the abolition or reproduction of the patient's pain symptoms. He compared precision diagnostic injections to the physical examination rather than most laboratory tests used in clinical medicine, which can have an absolute gold standard for comparison to determine their true accuracy because a tissue diagnostic confirmation can be accomplished. He warned that rather than concluding that these tests are useless or invalid, the multiple facts should be considered together with the inaccuracies that are present in all diagnostic tests in medicine.

Bogduk and McGuirk $(8-10,31)$ described in detail the accuracy and value of precision diagnostic blocks and proposed an algorithmic approach to diagnosis of chronic low back pain, defining the role of precision diagnostic blocks in the diagnosis and treatment of chronic low back pain.
Manchikanti et al (32), in an evidencebased evaluation of diagnostic interventional techniques provided strong affirmation of the validity, specificity, and sensitivity of facet joint nerve blocks in the diagnosis of spinal pain of facet joint origin.

In contrast, Nachemson and Vingård (39), in assessment of patients with neck and back pain, concluded that various studies outside imaging have rarely demonstrated clinical utility. Ramsey et al (40) found that diagnostic and treatment devices lacking in scientific rigor included facet blocks, discography and diagnostic nerve root infiltration, along with other tests including electromyogram, stress radiographs and flexion and extension $\mathrm{x}$-rays, bone scintigraphy, thermography, diagnostic ultrasound, and temporary external fixation. However, these authors failed to take into consideration the criteria of the International Association for the Study of Pain (IASP) (41), as well as the nature of controlled diagnostic blocks. Jaeschke et al (42) stated that the accuracy of a diagnostic test is best determined by comparing it to an appropriate reference standard such as biopsy, surgery, autopsy, or long-term follow-up (43). A gold or criterion standard allows accurate comparison of a given diagnostic test's capacity to yield positive results when the clinical condition is present and negative results when the clinical condition is not present. Thus, a gold or criterion standard facilitates accurate determination of the specificity and sensitivity of a test. Tissue confirmation of the presence or absence of a disease at surgery, with a biopsy, or autopsy, which has served as the accepted criterion standard across multiple medical disciplines, is not applicable to interventional pain management. Stability of the diagnosis over a long period of time with long-term follow-up may be also used as a criterion standard.

To demonstrate the validity of facet joint blocks, they must be performed utilizing IASP criteria (41), to avoid falsepositives. Thus, face validity and construct validity of facet joint blocks must be maintained. Ideally, all controlled blocks should include placebo injections of normal saline, but it may be neither logistical nor ethical to use placebo injections of normal saline in conventional practice in each and every patient. In addition, one may be required to perform three blocks of the same structure if a placebo is used. 
As an alternative, the use of comparative local anesthetic blocks, on two separate occasions, during which the same joint is anesthetized using two local anesthetics with different duration of actions, has been proposed $(6,11-13,44-46)$.

This systematic review was undertaken to determine the accuracy of facet or zygapophysial joint blocks in the diagnosis of chronic spinal pain.

\section{Materials and Methods}

\section{Literature Search}

The literature search included MEDLINE, EMBASE (Jan 1966-Mar 2003), systematic reviews, narrative reviews, cross-references to the reviews and various published trials; and peer reviewed abstracts from scientific meetings during the past two years. Available literature through March 2003 was utilized. The search strategy consisted of diagnostic interventional techniques, facet joint blocks or zygapophysial joint blocks, with emphasis on chronic pain/low back pain/ neck pain/mid back or thoracic pain or spinal pain.

\section{Selection Criteria}

The review focused on placebo-controlled and comparative local anesthetic block studies (observational studies) in which the facet or zygapophysial joint blocks were evaluated in a systematic fashion. The population of interest was patients suffering with chronic spinal pain of at least 3 months duration. The diagnostic test was facet joint block and the diagnostic criterion standard was at least $80 \%$ pain relief with maneuvers which were painful prior to the diagnostic block.
All the studies providing rationale, principles, validity, prevalence, and comparison to criterion standard were evaluated. The primary outcome measure was the accuracy with which facet joint pain was diagnosed. Secondary outcomes were falsepositive rates and complications.

For evaluating the quality of individual articles, we have used the criteria from the Agency for Healthcare Research and Quality (AHRQ) publication (47), which described domains and elements for diagnostic studies (Table 1).

\section{Data Extraction}

The algorithm used to evaluate the individual articles, including inclusion and exclusion criteria, is shown in Table 2. Studies that did not meet criteria were eliminated from consideration. Studies were excluded if there were no descriptions of appropriate outcomes or statistical analysis. Thus, for a study to be included, it had to meet at least 3 of the 5 criteria.

\section{REsULTS}

Relevant studies meeting the rationale, principles, and validity of facet joint blocks, and studies examining the prevalence of facet joint pain were evaluated. In prevalence estimations, only the studies utilizing controlled comparative local anesthetic blocks or placebo-controlled blocks were utilized. Studies confirming the criterion standard were also evaluated.

Facet or zygapophysial joint block is a diagnostic procedure designed to determine whether a facet joint is responsible for patient's pain. It includes proper placement of the needle, injection of local anesthetic, and assessment of patient's pain response. Facet joint blocks have been used extensively in the study of lumbar facet joints, somewhat less so in the study of cervical facet joints, and infrequently in the study of thoracic facet joint pain. Even though, originally introduced as a technique prior to fusion and a therapeutic technique, facet joint blocks are no longer utilized prior to fusion. They are most commonly utilized for diagnostic purposes to establish a diagnosis of facet or zygapophysial joint pain and to offer therapeutic options.

\section{Rationale}

The facet joints are well innervated by the medial branches of the dorsal rami (48-54). In the cervical spine below $\mathrm{C} 2 / 3$, the cervical facet joints are supplied by medial branches of the cervical dorsal rami above and below the joint, which also innervate the deep paramedian muscles. The $\mathrm{C} 2 / 3$ joint is supplied by the third occipital nerve $(48,55)$. In the thoracic and lumbar spine, the facet joints are innervated by medial branches of the dorsal rami of the spinal nerves except at L5 level. The L5 dorsal ramus divides into medial and lateral branches, with the medial branch continuing medially, innervating the lumbosacral joint $(56,57,59)$. Each segmental medial branch of the dorsal ramus supplies at least 2 (in humans, monkeys, and cats) or 3 (in rats) facet joints (50).

Cervical facet joints have been shown to be capable of being a source of neck pain and referred pain in the head or upper limb girdle; thoracic facet joints have been shown to be capable of being a source of thoracic pain and referred pain over the chest wall; and lumbar facet joints have been shown to be capable of being a source of low back pain and re-

Table 1. Domains and elements for diagnostic studies developed by the Agency for Healthcare Research and Quality (AHRQ)

\begin{tabular}{|l|l|}
\hline Domain & Elements* \\
\hline Study Population & $\begin{array}{l}\text { - Subjects similar to populations in which the test would be used and with a similar spectrum of } \\
\text { disease }\end{array}$ \\
Adequate Description of Test & - Details of test and its administration sufficient to allow for replication of study \\
Appropriate Reference Standard & - Appropriate reference standard ("gold standard") used for comparison \\
& - Reference standard reproducible \\
Blinded Comparison of Test and Reference & - Evaluation of test without knowledge of disease status, if possible \\
& - Independent, blind interpretation of test and reference \\
Avoidance of Verification Bias & - Decision to perform reference standard not dependent on results of test under study
\end{tabular}

*Elements appearing in italics are those with an empirical basis. Elements appearing in bold are those considered essential to give a system a Yes rating for the domain. 
Table 2. Study evaluation (inclusion/exclusion) algorithm

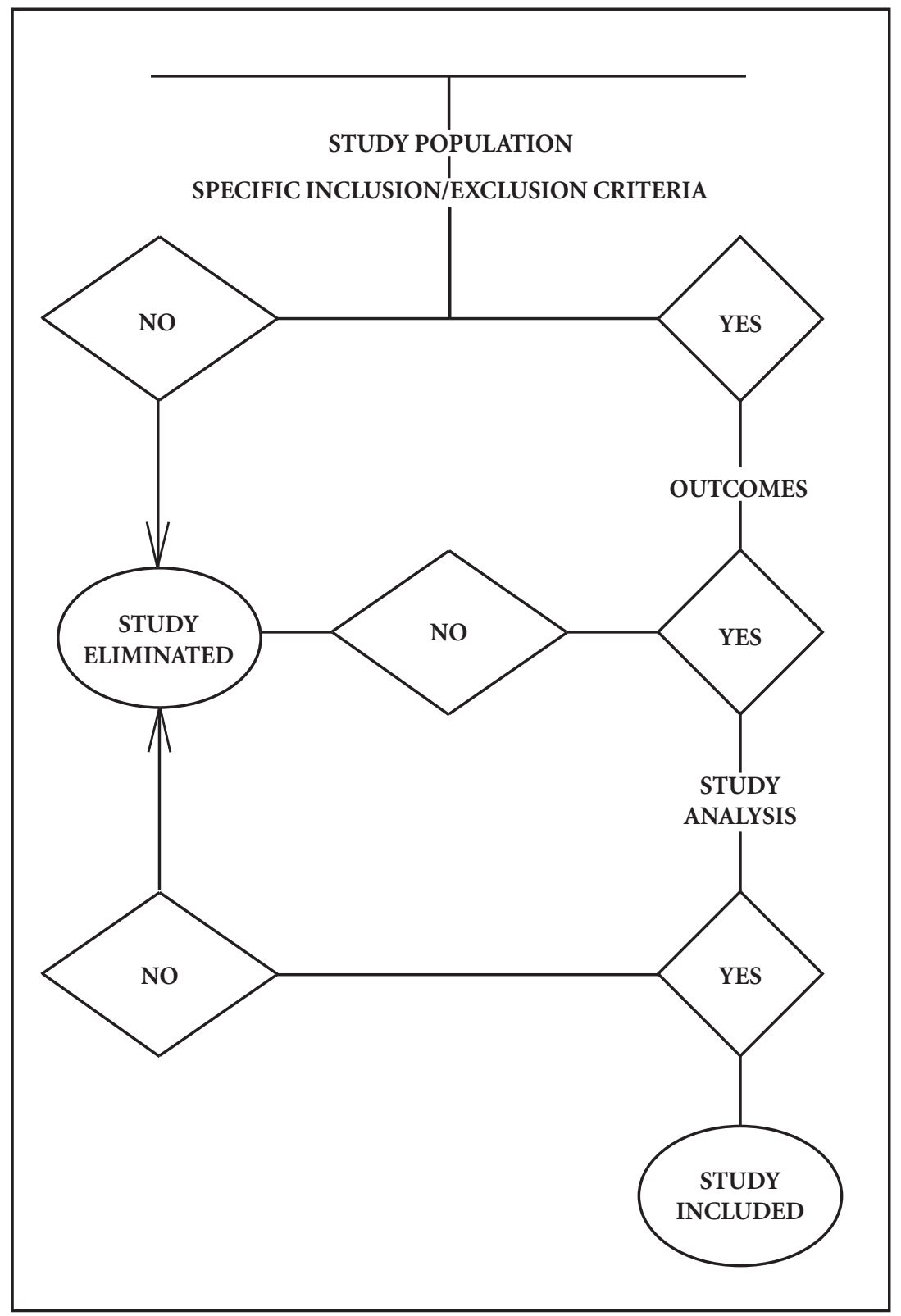

ferred pain in the lower limb in normal volunteers (60-70). There are no reliable clinical or radiological means of implicating zygapophysial or facet joints as the source of spinal pain in a given patient (4, $6,8,11,14-32,34,60-86)$.

\section{Principles}

Blocks of a facet or zygapophysial joint can be performed in order to test the hypothesis that the target joint is the source of the patient's pain (2, 6-10, 3134, 57-59). Facet joints can be anesthetized either with intraarticular injections secured by performing controlled blocks, either in the form of placebo injections of normal saline or comparative local anesthetic blocks, in which on two separate occasions, the same joint is anesthetized but using local anesthetics with different durations of action. Comparative local anesthetic blocks are readily implemented if medial branch blocks are used to anesthetize zygapophysial joints. They may not be implementable for intraarticular blocks, for it is not known whether placement of local anesthetic in a relatively avascular environment, such as a joint space, affects its expected duration of action. Further, an injected capsule may leak into the adjacent neural foramen and result in blockade of the dorsal root ganglion and segmental nerves (87-90).

Medial branch blocks are performed under fluoroscopic control. They involve introducing onto each of the two nerves that innervate the target joint. Each nerve can be anesthetized by injecting as little as $0.3 \mathrm{~mL}$ of local anesthetic. The average local anesthetic solution injected is approximately $0.5 \mathrm{~mL}$.

\section{Validity}

Medial branch blocks have been shown to have face validity. Local anesthetic injected accurately onto the correct target points selectively infiltrates the target nerve, and does not anesthetize any adjacent structures that might be an alternative source of pain to the zygapophysial joint $(57,58)$. In addition, medial branch blocks have been shown to protect normal volunteers from pain provoked experimentally from the anesthetized joint $(31,59)$.

Medial branch blocks also have shown to have construct validity. However, to have construct validity, medial branch blocks must be controlled. Single diagnostic blocks carry a false-positive rate of $27 \%$ to $63 \%$ in cervical spine, $58 \%$ in the thoracic spine, and $22 \%$ to $47 \%$ in lumbar spine (15-22, 27-30). Patients are liable to report relief of pain after a diagnostic block for reasons other than the pharmacologic action of drug administered (13). Thus, it is essential to know in every individual case whether the response is a true positive. The validity of controlled comparative local anesthetic blocks for facet joint diagnostic blocks was confirmed with placebo-controlled diagnostic blocks $(12,13)$. 
False-positive rate of diagnostic facet joint blocks evaluated in two groups of patients, either with diagnosis of somatization disorder or without such a diagnosis (91). This study showed that somatization or other psychological factors including depression and generalized anxiety disorders failed to influence the diagnostic validity of lumbar facet joint blocks. The diagnostic validity and therapeutic value of medial branch blocks with or without adjuvants was also evaluated (17). Based on this evaluation, there was no difference noted in the capacity to diagnose facet joint pain with local anesthetics administered alone or with mixtures of Sarapin or Sarapin and methylprednisolone.

\section{Criterion Standard}

No results of biopsy or autopsy were available to confirm specificity and sensitivity of medial branch blocks. However, other criterion standards accepted across multiple medical disciplines include pain relief $(12-30,91)$ and stability of the diagnosis over a long period of time with long-term follow up (92-99).

\section{Prevalence}

Multiple publications were examined to evaluate the diagnostic validity of facet joint blocks. Of these, only prospective evaluations that were performed under fluoroscopic guidance, with low volume injectate (less than $1 \mathrm{~mL}$ ) were examined, and only studies using placebocontrolled or comparative local anesthetic blocks were included. A total of 17 studies were evaluated for validity, prevalence, and false-positive rate (14-30). Based on these evaluations, facet or zygapophysial joints have been implicated as a source of chronic spinal pain in $15 \%$ to $45 \%$ of the heterogenous groups of patients with chronic low back pain (14-17, 25-27), $48 \%$ of the patients with thoracic pain (20), and $54 \%$ to $67 \%$ of the patients with chronic neck pain $(18,19,23,24)$. The prevalence of facet joint pain in the elderly, post lumbar laminectomy patients and in obese patients (28-30) were also evaluated showing significantly higher prevalence in elderly and non-surgical patients $(28,29)$. There were no differences noted in obese patients (30).

\section{Diagnostic Utility}

Establishing a diagnosis of facet or zygapophysial joint pain provides a valid diagnosis and also therapeutic options. It also obviates the need for any further investigations in the pursuit of a diagnosis. Prevalence of facet or zygapophysial joint pain provides significant pre-test and post-test probabilities. Successful management of facet joint pain has been reported with interventional techniques (92-99).

\section{Strength of Evidence}

Based on the review of all the available studies meeting our inclusion criteria, there is conclusive evidence that facet joints are innervated, are capable of causing pain similar to that seen clinically, and are a source of pain in patients, with chronic spinal pain, and there is strong evidence that controlled diagnostic facet joint blocks to establish diagnosis of facet joint pain in chronic spinal pain.

\section{Complications}

There were no complications reported with diagnostic facet or zygapophysial joint blocks performed under fluoroscopy with low volume local anesthetic injection with or without adjuvants.

\section{DISCUSSION}

Our review shows that diagnostic facet (zygapophysial) joint blocks are safe, valid, and reliable, with a significant and variable false-positive rate. When performed under fluoroscopic visualization utilizing IASP (41) criteria, facet joint blocks are accurate and clinically useful in the diagnosis and therapeutic management of chronic spinal pain. The diagnostic accuracy of facet or zygapophysial joint blocks is strong to conclusive. In contrast, facet joint pain cannot be diagnosed or excluded with high level of certainty without precision diagnostic interventional techniques.

The strength of our review is based on its compliance with criteria for evaluating diagnostic tests as established by AHRQ (47). These were described as important domains and elements for diagnostic studies, which included: study population, adequate description of the test, appropriate reference standard, blinded comparison of test, and reference and avoidance of verification bias. Overall, this review met the criteria described by Bogduk (5) with nerve supply, production of pain similar to that seen clinically in normal volunteers, facet joints as a source of pain in patients using precision diagnostic facet or zygapophysial joint blocks, unreliability of provocation, and a significant false-positive rate with single blocks.

The inability of a physician to provide appropriate and accurate diagnosis for a patient with chronic spinal pain is frustrating for the patient and the doctor. Although the history and physical examination alone are not diagnostic in a majority of patients with chronic spinal pain, they provide appropriate understanding of the nature of the problem and are important tools in screening for neurological problems and other red flag indicators. Psychological assessment may assist in identification of patients with psychiatric and behavioral problems. Radiological investigation may identify anatomic problems, such as disc herniation, highintensity zone lesions, and vertebral endplate changes which indicate the presence of disc-related pain (34). However, imaging studies can not discern whether a particular anatomic finding hurts. However, precision diagnostic interventional techniques can identify a painful lesion, and are of paramount importance in formulation of an anatomic diagnosis.

One of the major criticisms of our findings is that none of the studies were validated with "criterion standard" tests, such as autopsy, surgical findings, or biopsy. However, our review confirms the validity of facet joint blocks as a reliable diagnostic tool, comparing not only immediate pain relief with maneuvers which were previously painful, but on the basis of a predictable and demonstrable falsepositive rate, and the potential for providing therapeutic benefits on a longterm basis. 


\section{Author Affiliation:}

Mark V. Boswell, MD, PhD

Associate Professor of Anesthesiology

Chief, Division of Pain Medicine

Department of Anesthesiology

Director, Pain Medicine Fellowship

Program

Case Western Reserve University

School of Medicine and University

Hospitals of Cleveland

11100 Euclid Avenue

Cleveland, Ohio-44106

E-mail: mark.boswell@uhhs.com

\section{Vijay Singh, MD}

Medical Director

Pain Diagnostics Associates

1601 Roosevelt Road

Niagara, Wisconsin 54151

E-mail vsingh@netnet.net

\section{Peter S. Staats, MD,}

Director, Division of Pain Medicine, Associate Professor of Anesthesiology and Critical Care Medicine and of Oncology,

John Hopkins University School

of Medicine,

550 N. Broadway, Suite 301,

Baltimore, MD 21205

E-mail pstaats@jhmi.edu

\section{Joshua A. Hirsch, MD}

Harvard School of Medicine

Department of Interventional

Radiology

Massachusetts General Hospital

55 Blossom St. Gray 289

Boston, Massachusetts 02114

E-mail: jahirsch@partners.org

\section{REFERENCES}

1. Deyo RA, Weinstein JN. Low back pain. $N$ Engl J Med 2001; 344:363-370.

2. Kirwan EO. Back pain. In: Wall PD, Melzack R (eds). Text Book of Pain. $2^{\text {nd }}$ ed. Churchill Livingstone, Edinburgh, 1989: 335-340.

3. Deyo RA, Rainville J, Kent DL. What can the history and physical examination tell us about low back pain? JAMA 1992; 268: 760-765.

4. Bogduk N, McGuirk B. Causes and sources of chronic low back pain. In: Bogduk N, McGuirk B (eds). Medical Management of Acute and Chronic Low Back pain. An Evidence-Based Approach: Pain Research and Clinical Management, Vol. 13, Elsevier Science BV, Amsterdam, 2002:115-126.

5. Bogduk N. Low back pain. In Clinical
Anatomy of the Lumbar Spine and Sacrum, ed 3. Churchill Livingstone, New York, 1997; pp 187-214.

6. Bogduk N. International Spinal Injection Society guidelines for the performance of spinal injection procedures. Part 1: Zygapophyseal joint blocks. Clin J Pain 1997; 13:285-302.

7. Hildebrandt J. Relevance of nerve blocks in treating and diagnosing low back pain is the quality decisive? Schmerz 2001; 15: 474-483.

8. Bogduk N, McGuirk B. An algorithm for precision diagnosis. In: Bogduk N, McGuirk B (eds). Medical Management of Acute and Chronic Low Back pain. An Evidence-Based Approach: Pain Research and Clinical Management, Vol. 13, Elsevier Science BV, Amsterdam, 2002:177-186.

9. Bogduk N, McGuirk B. Precision treatment. In: Bogduk N, McGuirk B (eds). Medical Management of Acute and Chronic Low Back pain. An Evidence-Based Approach: Pain Research and Clinical Management, Vol. 13, Elsevier Science BV, Amsterdam, 2002:187-198.

10. Bogduk N, McGuirk B. An approach to chronic low back pain. In: Bogduk N, McGuirk B (eds). Medical Management of Acute and Chronic Low Back pain. An Evidence-Based Approach: Pain Research and Clinical Management, Vol. 13, Elsevier Science BV, Amsterdam, 2002:199-204.

11. Bogduk N, Lord S. Cervical zygapophysial joint pain. Neurosurgery 1998; 8:107-117.

12. Barnsley L, Lord S, Bogduk N. Comparative local anesthetic blocks in the diagnosis of cervical zygapophysial joints pain. Pain 1993; 55:99-106.

13. Lord SM, Barnsley L, Bogduk N. The utility of comparative local anesthetic blocks versus placebo-controlled blocks for the diagnosis of cervical zygapophysial joint pain. Clin J Pain 1995; 11:208-213.

14. Schwarzer AC, Aprill CN, Derby $R$ et al. Clinical features of patients with pain stemming from the lumbar zygapophysial joints. Is the lumbar facet syndrome a clinical entity? Spine 1994; 19:1132-1137.

15. Manchikanti L, Pampati V, Fellows B et al. Prevalence of lumbar facet joint pain in chronic low back pain. Pain Physician 1999; 2:59-64

16. Manchikanti L, Pampati V, Fellows B et al. The inability of the clinical picture to characterize pain from facet joints. Pain Physician 2000; 3:158-166.

17. Manchikanti L, Pampati V, Fellows B et al. The diagnostic validity and therapeutic value of medial branch blocks with or without adjuvants. Curr Rev Pain 2000; 4: 337-344.

18. Manchikanti L, Singh V, Rivera J et al. Prevalence of cervical facet joint pain in chronic neck pain. Pain Physician 2002; 5:243249.

19. Manchikanti L, Singh V, Pampati V et al. Is there correlation of facet joint pain in lum- bar and cervical spine? Pain Physician 2002; 5:365-371.

20. Manchikanti L, Singh, V, Pampati V et al. Evaluation of the prevalence of facet joint pain in chronic thoracic pain. Pain Physician 2002; 5:354-359.

21. Schwarzer AC, Aprill CN, Derby R et al. The false-positive rate of uncontrolled diagnostic blocks of the lumbar zygapophysial joints. Pain 1994; 58:195-200.

22. Barnsley L, Lord S, Wallis B et al. Falsepositive rates of cervical zygapophysial joint blocks. Clin J Pain 1993; 9:124-130.

23. Barnsley L, Lord SM, Wallis BJ et al. The prevalence of chronic cervical zygapophyseal joint pain after whiplash. Spine 1995; 20:20-26.

24. Lord SM, Barnsley L, Wallis BJ et al. Chronic cervical zygapophysial joint pain with whiplash: A placebo-controlled prevalence study. Spine 1996; 21:1737-1745.

25. Schwarzer AC, Aprill CN, Derby R et al. The relative contributions of the disc and zyg. apophyseal joint in chronic low back pain. Spine 1994; 19:801-806.

26. Schwarzer AC, Wang SC, Bogduk N et al. Prevalence and clinical features of lumbar zygapophysial joint pain: A study in an Australian population with chronic low back pain. Am Rheum Dis 1995; 54:100106.

27. Manchikanti L, Singh V, Pampati V et al. Evaluation of the relative contributions of various structures in chronic low back pain. Pain Physician 2001; 4:308-316.

28. Manchikanti L, Pampati V, Baha A et al. Contribution of facet joints to chronic low back pain in postlumbar laminectomy syndrome: A controlled comparative prevalence evaluation. Pain Physician 2001; 4: 175-180.

29. Manchikanti L, Pampati V, Rivera J et al. Role of facet joints in chronic low back pain in the elderly: A controlled comparative prevalence study. Pain Practice 2001; 1:1-6.

30. Manchikanti L, Pampati V, Singh V et al. Evaluation of the role of facet joints in persistent low back pain in obesity: A controlled, prospective, comparative evaluation. Pain Physician 2001; 4:266-272.

31. Bogduk N, McGuirk B. Precision diagnosis. In: Bogduk N, McGuirk B, eds. Medical Management of Acute and Chronic Low Back pain. An Evidence-Based Approach: Pain Research and Clinical Management, Vol. 13. Elsevier Science BV, Amsterdam, 2002:169-176.

32. Manchikanti L, Staats P, Singh V et al. Evidence-based practice guidelines for interventional techniques in the management of chronic spinal pain. Pain Physician 2003; 6:3-80.

33. Saal JS. General principles of diagnostic testing as related to painful lumbar spine disorders. Spine 2002; 27:2538-2545.

34. Bogduk N, McGuirk B. Assessment. In: Bogduk N, McGuirk B (eds). Medical 
Management of Acute and Chronic Low Back pain. An Evidence-Based Approach: Pain Research and Clinical Management, Vol. 13. Elsevier Science BV, Amsterdam, 2002:127-138.

35. Frymoyer W. Epidemiology. In Frymoyer JW, Gordon SL (eds). New Perspectives on Low Back Pain. American Academy of Orthopaedic Surgeons, Park Ridge, 1989:1933.

36. Quebec Task Force on Spinal Disorders. Scientific approach to the assessment and management of activity-related spinal disorders: A monograph for clinicians. Spine 1987; 12:S1-S59.

37. Kuslich SD, Ulstrom CL, Michael CJ. The tissue origin of low back pain and sciatica: A report of pain response to tissue stimulation during operation on the lumbar spine using local anesthesia. Orthop Clin North Am 1991; 22:181-187.

38. Hogan QH, Abram SE. Neural blockade for diagnosis and prognosis. Anesthesiology 1997; 86:216-241.

39. Nachemson A, Vingård E. Assessment of patients with neck and back pain: $A$ best-evidence synthesis. In Nachemson A, Vingård E (eds). Neck and back pain. The scientific evidence of causes, diagnosis and treatment. Lippincott Williams \& Wilkins, Philadelphia, 2000:189-236.

40. Ramsey SD, Luce BR, Deyo $R$ et al. The limited state of technology assessment for medical devices: Facing the issues. $A m$ J Managed Care 1998; 4:188-199.

41. Merskey H, Bogduk N. Classification of chronic pain. In Merskey $\mathrm{H}$, Bogduk $\mathrm{N}$ (eds). Descriptions of Chronic Pain Syndromes and Definition of Pain Terms, $2^{\text {nd }}$ ed. IASP Press, Seattle, 1994:180-181.

42. Jaeschke R, Guyatt G, Lijmer J. Diagnostic tests. In Guyatt G, Rennie D (eds). Users' Guides to the Medical Literature - A Manual for Evidence-Based Clinical Practice. AMA Press, Chicago, 2002:121-140.

43. Sackett DL, Haynes RB, Guyatt GH et al. Clinical Epidemiology, A Basic Science for Clinical Medicine. $2^{\text {nd }}$ ed. Little, Brown and Company, Boston, 1991:53-57.

44. Bonica JJ. Local anesthesia and regional blocks. In: Wall PD, Melzack R (eds). Textbook of Pain, $2^{\text {nd }}$ ed. Churchill Livingstone, Edinburg, 1989:724-743.

45. Bonica JJ, Buckley FP. Regional analgesia with local anesthetics. In Bonica JJ (ed). The Management of Pain. Lea \& Febiger, Philadelphia, 1990; 2:1883-1966.

46. Boas RA. Nerve blocks in the diagnosis of low back pain. Neurosurg Clin North Am 1991; 2:806-816.

47. Systems to rate the strength of scientific evidence. Evidence Report/Technology Assessment No. 47 University of North Carolina: Agency for Healthcare Research and Quality. AHRQ Publication No. 02E016; April 2002.

48. Bogduk N. The clinical anatomy of the cervical dorsal rami. Spine 1982; 7:35-45.
49. Bogduk N, Wilson AS, Tynan W. The human lumbar dorsal rami. J Anat 1982; 134: 383-397.

50. Suseki K, Takahashi Y, Takahashi K et al. Innervation of the lumbar facet joints. Spine 1997; 22:477-485.

51. Bogduk N. The innervation of the lumbar spine. Spine 1983; 8:286-293.

52. Chua WH, Bogduk N. The surgical anatomy of thoracic facet denervation. Acta Neurochir 1995; 136:140-144.

53. Stilwell DL. The nerve supply of the vertebral column and its associated structures in the monkey. Anat Rec 1956; 125:139169.

54. Cavanaugh JM, Ozaktay AC, Yamashita HT et al. Lumbar facet pain: Biomechanics, neuroanatomy, and neurophysiology. J Biomech 1996; 29:1117-1129.

55. Bogduk N, Marsland A. On the concept of third occipital headache. J Neurol Neurosurg Psychiatry 1986; 49:775-780.

56. Bogduk N, Long D. The anatomy of the so-called "articular nerves" and their relationship to facet denervation in the treatment of low back pain. J Neurosurg 1979; 51:172-177.

57. Dreyfuss $P$, Schwarzer AC, Lau $P$ et al. Specificity of lumbar medial branch and $L_{5}$ dorsal ramus blocks. Spine 1997; 22:895902.

58. Barnsley L, Bogduk N. Medial branch blocks are specific for the diagnosis of cervical zygapophyseal joint pain. Reg Anesth $1993 ; 18: 343-350$.

59. Kaplan M, Dreyfuss P, Halbrook B et al. The ability of lumbar medial branch blocks to anesthetize the zygapophysial joint. Spine 1998; 23:1847-1852.

6o. Fukui S, Ohseto K, Shiotani M et al. Referred pain distribution of the cervical zygapophyseal joints and cervical dorsal rami. Pain 1996; 68:79-83.

61. Dwyer A, Aprill C, Bogduk N. Cervical zygapophyseal joint pain patterns: A study in normal volunteers. Spine 1990; 6:453-457.

62. Aprill C, Dwyer A, Bogduk N. The prevalence of cervical zygapophyseal joint pain patterns II: A clinical evaluation. Spine 1990; 6:458-461.

63. Pawl RP. Headache, cervical spondylosis, and anterior cervical fusion. Surg Ann 1977; 9:391-498.

64. Dreyfuss P, Tibiletti C, Dreyer SJ. Thoracic zygapophyseal joint pain patterns: A study in normal volunteers. Spine 1994; 19:807-811.

65. Mooney V, Robertson J. The facet syndrome. Clin Orthop 1976; 115:149-156.

66. McCall IW, Park WM, O’Brien JP. Induced pain referral from posterior elements in normal subjects. Spine 1979; 4:441-446.

67. Marks R. Distribution of pain provoked from lumbar facet joints and related structures during diagnostic spinal infiltration. Pain 1989; 39:37-40.

68. Fukui S, Ohseto K, Shiotani M et al. Dis- tribution of referral pain from the lumbar zygapophyseal joints and dorsal rami. Clin J Pain 1997; 13:303-307.

69. Hirsch C, Ingelmark BE, Miller M. The anatomical basis for low back pain. Acta Orthop Scand 1963; 33:1-17.

70. Windsor RE, King FJ, Roman SJ et al. Electrical stimulation induced lumbar medial branch referral patterns. Pain Physician 2002; 5:347-353.

71. Schwarzer AC, Derby R, Aprill CN et al. The value of the provocation response in lumbar zygapophysial joint injections. Clin J Pain 1994; 10:309-313.

72. Helbig T, Lee CK. The lumbar facet syndrome. Spine 1988; 13:61-64.

73. Revel ME, Listrat VM, Chevalier XJ et al. Facet joint block for low back pain: Identifying predictors of a good response. Arch Phys Med Rehabil 1992; 73:824-828.

74. Raymond J, Dumas JM. Intraarticular facet block: Diagnostic tests or therapeutic procedure? Radiology 1989; 151:333-336.

75. Schwarzer AC, Derby R, Aprill CN et al. Pain from the lumbar zygapophysial joints: A test of two models. J Spinal Disord 1994; 7:331-336.

76. Jackson RP, Jacobs RR, Montesano PX. Facet joint injection in low back pain. A prospective statistical study. Spine 1988; 13:966-971.

77. Jónsson $\mathrm{H}$, Bring $\mathrm{G}$, Rauschning $\mathrm{W}$ et al. Hidden cervical spine injuries in traffic accident victims with skull fractures. J Spinal Dis 1991; 4:251-263.

78. Taylor JR, Twomey LT. Acute injuries to cervical joints: An autopsy study of neck sprain. Spine 1993; 9:1115-1122.

79. Schwarzer AC, Wang SC, O'Driscoll D et al. The ability of computed tomography to identify a painful zygapophysial joint in patients with chronic low back pain. Spine 1995; 20:907-912.

8o. Binet EF, Moro JJ, Marangola JP et al. Cervical spine tomography in trauma. Spine 1977; 2:163-172.

81. Abel MS. Occult traumatic lesions of the cervical vertebrae. Critical Rev Clin Radiol Nuclear Med 1975; 6:469-553.

82. Woodring JH, Goldstein SJ. Fractures of the articular processes of the cervical spine. Am J Roentgenol 1982; 139:341-344.

83. Magora A, Bigos SJ, Stolov WC et al. The significance of medical imaging findings in low back pain. Pain Clinic 1994; 7:99-105.

84. Murtagh FR. Computed tomography and fluoroscopy guided anesthesia and steroid injection in facet syndrome. Spine 1988; 13:686-689.

85. Destout JM, Murphy WA. Lumbar facet blocks: Indications and techniques. Orthop Review 1985; 14:57-65.

86. Schwarzer AC, Scott AM, Wang SC et al. The role of bone scintigraphy in chronic low back pain: A comparison of SPECT and planar images and zygapophysial joint injection. Aust NZJ Med 1992; 22:185. 
87. Destout JM, Gilula LA, Murphey WA et al. Lumbar facet joint injection: Indication, technique, clinical correlation and preliminary results. Radiology 1982; 145:321325.

88. Moran R, O'Connell D, Walsh MG. The diagnostic value of facet joint injections. Spine 1988; 13:1407-1410.

89. Dory MA. Arthrography of the cervical facet joints. Radiology 1983; 148:379-382.

90. Dory MA. Arthrography of the lumbar facet joints. Radiology 1981; 140:23-27.

91. Manchikanti L, Pampati V, Fellows B et al. Influence of psychological factors on the ability of diagnose chronic low back pain of facet joint origin. Pain Physician 2001; 4:349-357.
92. Lord SM, Barnsley L, Wallis BJ et al. Percutaneous radio-frequency neurotomy for chronic cervical zygapophyseal-joint pain. N Engl J Med 1996; 33523:1721-1726.

93. van Kleef M, Barendse GA, Kessels A et al. Randomized trial of radiofrequency lumbar facet denervation for chronic low back pain. Spine 1999; 24:1937-1942.

94. McDonald GJ, Lord SM, Bogduk N. Longterm follow-up of patients treated with cervical radiofrequency neurotomy for chronic neck pain. Neurosurgery 1999; 45:61-68.

95. Sapir D, Gorup JM. Radiofrequency medial branch neurotomy in litigant and nonlitigant patients with cervical whiplash. Spine 2001; 26:E268-E273.
96. Stolker RJ, Vervest AC, Groen GJ. Percutaneous facet denervation in chronic thoracic spinal pain. Acta Neurochir 1993; 122: 82-90.

97. Manchikanti L, Pampati V, Bakhit CE et al. Effectiveness of lumbar facet joint nerve blocks in chronic low back pain: A randomized clinical trial. Pain Physician 2001; 4: 101-117.

98. Manchikanti L, Singh V, Pampati S. Are diagnostic lumbar medial branch blocks valid? Results of 2-year follow-up. Pain Physician 2003; 5:146-152.

99. Manchikanti L, Singh V, Vilims B et al. Medial branch neurotomy in management of chronic spinal pain: Systematic review of the evidence. Pain Physician 2002; 5:405-418. 